\title{
A koronária-CT-angiográfia értelmezése és leletezése
}

A Magyar Kardiológusok Társasága Kardiovaszkuláris Képalkotó Munkacsoportjának ajánlása

\author{
Bartykowszki Andrea1, Tóth Levente², Kerecsen Gábor³, \\ Jermendy Ádám Levente', Kolossváry Márton', Karády Júlia', \\ Szilveszter Bálint', Károlyi Mihály', Suhai Ferenc Imre', Panajotu Alexisz', \\ Kolozsvári Rudolf ${ }^{4}$, Balázs György ${ }^{1}$, Hüttl Kálmán', Thury Attila', \\ Battyány István², Kiss Róbert Gábor³, Merkely Béla1', Maurovich-Horvat Pál ${ }^{1}$
}

${ }^{1}$ MTA-SE Lendület Kardiovaszkuláris Képalkotó Kutatócsoport, Semmelweis Egyetem, Városmajori Szív- és Érgyógyászati Klinika, Budapest, ${ }^{2}$ Pécsi Tudományegyetem, Radiológiai Klinika, Pécs, ${ }^{3}$ Magyar Honvédség Egészségügyi Központ, Kardiológiai Osztály, Budapest, ${ }^{4}$ Debreceni Egyetem, Orvos- és Egészségtudományi Centrum, Kardiológiai Intézet, Debrecen, ${ }^{5}$ Szegedi Tudományegyetem, II. sz. Belgyógyászati Klinika és

Kardiológiai Központ, Szeged

Levelezési cím: Dr. Maurovich-Horvat Pál, PhD, MPH, 1122 Budapest, Városmajor u. 68., E-mail: p.maurovich-horvat@cirg.hu

\section{Preambulum}

A Magyar Kardiológusok Társasága Kardiovaszkuláris Képalkotó Munkacsoportjának és a Magyar Radiológusok Társasága Szív Képalkotó Diagnosztikai Szekciójának konszenzusdokumentumának 2013-as megjelenése óta a koronária komputertomográfiás angiográfia (CCTA) jelentős fejlödésen ment keresztül. A technikai újitások eredményeként funkcionális vizsgálatok végzése vált lehetővé, továbbá nemzetközi vizsgálatok eredményei alapján a szakmai ajánlások a CCTA új indikációval bővültek.

Mindezen változások miatt a Magyar Kardiológusok Társasága Kardiovaszkuláris Képalkotó Munkacsoportja szükségét érzi, hogy a felvételek értelmezéséhez, valamint a lelet elkészítéséhez korábban megfogalmazott szakmai állásfoglalását a Society of Cardiovascular Computed Tomography (SCCT) által kiadott ajánlás alapján átdolgozza (1).

Jelen dokumentumnak nem célja a CCTA indikációinak és kontraindikációinak részletezése. Tekintettel a kardiovaszkuláris betegségek nagyszámú megjelenési formájára és az egyes esetek közötti magas variabilitásra, az alábbiakban részletezett irányelvektöl, ajánlásoktól egyedi mérlegelés alapján eltérhetünk.

\section{Bevezetés}

A koszorúér-betegség kimutatására alkalmazott noninvazív képalkotó módszerek közül az egyik legmodernebb eljárás a CCTA-vizsgálat, amelynek segítségével direkt információt nyerhetünk a koronáriákat érintö ateroszklerotikus plakkokról és a lumenszükület mértékéröl. A megfelelően kivitelezett, jó minőségű CCTA igen nagy szenzitivitással (kb. 95-100\%) és specificitással (>90\%) képes azonosítani a súlyos fokú koszorúer-szükületeket. A vizsgálat negatív prediktív értéke átlagosan $95-100 \%(2,3)$.
Az ateroszklerotikus folyamatok okozta koronáriaszükület mértékének meghatározásában az invazív koronária-angiográfiát (ICA) tekintjük referencia standardnak. A noninvazív CCTA legfontosabb indikációja - magas negatív prediktív értékének köszönhetően - a koronáriabetegség kizárása.

A CCTA-vizsgálat az ICA-hoz képest többletinformációt nyújt a nonobstruktív koronáriaplakkok jelenléte, a plakk-komponensek megoszlása, valamint egyéb, nem koronáriás kardiális képletek tekintetében (4-8). Továb- 
bá értékes információ nyerhető a leképezésre kerülő extrakardiális szervekröl is.

\section{A koronáriarendszer komputertomográfiás vizsgálata}

A koszorúérrendszer CT-vel történő vizsgálatához elengedhetetlen a vizsgáló orvos jártassága a szív anatómiájában, az ateroszklerotikus folyamatok patofiziológiájában, valamint a szív fejlődési rendellenességeiben. Magabiztosan kell elkülönítenie a patológiás állapotokat mind natív, mind kontrasztos felvételeken. Tisztában kell lennie a CT-technika limitációival, fel kell ismernie az értékelést esetlegesen tévútra vivô müterméket. A leletező orvosnak nagy jártassággal kell bírnia koszorúér-betegség terápiája során alkalmazott kardiológiai és sebészeti eljárásokban. Tisztában kell lennie a stentek és bypassgraftok típusával, valamint a graftok lefutásával. A sebészeti implantátumok (például billentyük) típusainak ismerete elengedhetetlen. Mindez lehetővé teszi a korrekt diagnózis felállítását.

A koszorúerek háromdimenziós ábrázolásához szubmilliméteres, izotropikus felbontást, gyors leképezést és EKG-kapuzott rögzítését lehetővé tevő CT-készülék szükséges. Koronáriavizsgálatokra széles detektorsorral (64 vagy nagyobb szeletszámú) és rövid rotációs idővel $(\leq 350 \mathrm{~ms})$ rendelkező CT-készülékek használata kívánatos. A vizsgálatok során törekedni kell a diagnosztikus képminőség elérésére adekvát sugárdózis alkalmazásával. Az ALARA- (as low as reasonably achievable) elv értelmében javasolt a csőáram- és csöfeszültség-beállítások optimalizálása a beteg testsúlya és testalkata függvényében, valamint sugárkímélő felvételezési protokollok használata. A CCTA-vizsgálat során a nagy koncentrációjú $(\geq 350 \mathrm{mg} / \mathrm{ml})$ jódos kontrasztanyagok alkalmazása ajánlott. A magas intrakoronáriás attenuáció, a jel/zaj arány javításával kisebb csőfeszültség és csőáram használatát teszi lehetővé. Amennyiben a koszorúerek vizsgálata képezi a fő indikációt, megfelelő szívfrekvencia esetén javasolt az alacsonyabb sugárterheléssel járó prospektíven EKG-triggerelt (axiális) felvételezési mód alkalmazása a retrospektíven EKG-kapuzott (helikális) adatrögzítéssel szemben. A koronáriafelvételeket javasolt a lehető legvékonyabb szeletvastagság alkalmazásával rekonstruálni. Fontos hangsúlyozni, hogy nagy jártasság szükséges a kiértékelő munkaállomások használatában.

\section{A nem kontrasztos koszorúér-vizsgálat értékelése: koronária-kalciumpontérték, Ca-scoring}

A koronáriarendszer, illetve a szív natív vizsgálata számos centrumban a rutinvizsgálati protokoll részét képezi, míg más központokban elvégzése opcionális. A prospektív triggereléssel elvégzett vizsgálat általában 0,5-1,5 mSv többletet jelent az effektív sugárterhelésben, ezért rutinprotokollban tartása a CCTA-vizsgálat mellett mérlegelendő. $A$ kontraszt nélküli felvételeken szemiautomatizált értékelőprogramok használatával a $130 \mathrm{HU}$ vagy nagyobb sugárgyengítésủ pixeleket azonosítjuk kalciumként. Az értékelést végző orvos feladata, hogy azonosítsa a koszorúerek lefutása mentén az összes kalcifikált léziót, és azokat a megfelelő koszorúérhez rendelje. A kalcifikáció mértékét pontrendszerek segítségével jellemezzük. Az összesített pontérték (score) számolásának egyik módja a területdenzitáson alapuló Agatston-score, míg a másik a kalcifikált léziók térfogatszámításán alapuló pontrendszer (9). A meszes léziók tömegét értékelő „mass-score” a mindennapi klinikai gyakorlatban kevésbé honosodott meg (10).

Az összesített koronária-Ca-score számításánál az aortafalban, az aorta és a mitralis billentyün, a peri- és a myocardiumban ábrázolódó kalcifikációt nem számítjuk be.

\section{A kontrasztos koszorúér-vizsgálat értékelése: koronária-CT-angiográfia}

A koronáriarendszer anatómiája

A koronáriarendszer standard módon történő értelmezése elengedhetetlen fontosságú az ateroszklerotikus léziók és szűkületek precíz leírásához és így az ország különbözö CCTA-centrumaiban készített leletek egységesítéséhez. A nemzetközi összehasonlíthatóság érdekében az angol rövidítések használatát ajánljuk (1. táblázat).

Az American Heart Association (AHA) által kidolgozott szegmentációs rendszer a legelterjedtebb a klinikai gyakorlatban. A Society of Cardiovascular Computed Tomography (SCCT) ajánlása ezt a szegmentációs rendszert vette alapul, amelyen két változtatást hajtottak végre a CCTA-vizsgálathoz igazodva. A módosított szegmentációs rendszer 18 szegmensre osztja fel a koszorúereket. A 18-as szegmentum a bal posterolateralis ág (PLB-LCX), illetve a 17-es szegmentum a ramus intermedius (IM) ág (2. táblázat).

\begin{tabular}{|c|c|c|}
\hline Rövidítés & Angol elnevezés & Magyar elnevezés \\
\hline RCA & Right coronary artery & Jobb koszorúér \\
\hline LM & Left main & Bal fötörzs \\
\hline LAD & $\begin{array}{l}\text { Left anterior descending } \\
\text { artery }\end{array}$ & Bal elülső leszálló ág \\
\hline LCX & Left circumflex artery & Bal körbefutó ág \\
\hline PLB & Posterior-lateral branch & Posterolateralis ág \\
\hline D & Diagonal branch & Diagonális ág \\
\hline OM & Obtuse marginal branch & Marginális obtusa ág \\
\hline PDA & $\begin{array}{l}\text { Posterior descending } \\
\text { artery }\end{array}$ & Hátulsó leszálló ág \\
\hline
\end{tabular}


2. TÁBLÁZAT. A koronáriarendszer felosztása a módosított, 18 szegmenses AHA-modell szerint

\section{Szegmentum Leírás}

1. Proximális RCA Az RCA eredésétöl a jobb kamra laterális széléig-szegletéig mért távolság feléig

2. Középső RCA A proximális szakasz végétöl a jobb kamra laterális széléig

3. Distalis RCA Az RCA középső szakaszának végétől a PDA eredéséig

4. PDA-RCA RCA-ból eredő PDA

16. PLB-RCA RCA-ból eredő PLB

5. LM A fötörzs eredésétöl a főtörzs oszlásáig (LAD, CX eredéséig)

6. Proximális LAD A fötörzs oszlásától a proximálisabb oldalág (első septalis vagy az első diagonális ág) leadásáig

7. Középső LAD A proximális szakasz végétől az apexig mért távolság feléig

8. Distalis $L A D$

A középső szakasz végétől a $L A D$ végéig

9. D1

10. D2

Az első diagonális ág

11. Proximális LCX

A második diagonális ág

A CX eredésétől az első OM-ág eredéséig

12. OM1

13. Középső és distalis LCX

14. OM2

15. PDA-LCX

17. IM

18. PLB-LCX

Első OM-ág, amely a bal kamra lateralis falán átlósan fut le

Az első OM-ág eredésétöl az ér végéig, vagy az L-PDA eredéséig az atrioventricularis árokban futó ág

Második OM-ág

Az LCX-ből eredő PDA

A fötörzs trifurkációja esetén a LAD és az LCX között eredő ág

Az LCX-ből eredő PLB

A lumenszükület, illetve a plakk kiterjedésének mérésére CT-felvételeken számos értékelő szoftver érhető el. Az e módszerekkel történő mérések pontossága, reprodukálhatósága azonban elmarad az invazív koronária-angiográfiáéhoz (ICA) képest, így alkalmazásuk nem képezi a napi rutin részét. Számos vizsgálat igazolta, hogy a CCTA-val mért koronáriaátmérő-szükület jó korrelációt mutat az invazív kvantitatív angiográfiával (QCA) és az intravaszkuláris ultrahanggal (IVUS) meghatározott értékekkel, azonban a standard deviáció viszonylag nagy $(11,12)$. Mindezek figyelembevételével, a CCTA-leleteken a vizuális becsléssel megállapított átméröszükületet javasolt feltüntetni, és opcionálisan a szükület mértékét széles tartományban javasolt megadni $(13,14)$. A szükület mértékének osztályozására ajánlott beosztás a 3. táblázatban szerepel. Az elzáródott érszakaszokról fontos megjegyezni, hogy krónikus, illetve akut elzáródások esetén is előfordulhat az elzáródástól distalisan jelentős mennyiségű kontrasztanyag
3. TÁBLÁZAT. A koronáriaszűkület mértékének javasolt osztályozása

0. Normális Ateroszklerózis, Ateroszklerózis, lumenlumenszűkület nem szükület nem látható látható

1. Minimális Átmérőszükület Ateroszklerózis, amely a mértéke $<25 \%$ lument nem befolyásolja

2. Enyhe Átmérőszűkület Áramlást nem befolyásomértéke $25-49 \%$ ló szükület

3. Közepes Átmérőszűkület Áramlást esetlegesen mértéke $50-69 \%$ befolyásoló szükület

4. Súlyos Átmérőszűkület Áramlást valószínűleg mértéke $70-99 \%$ befolyásoló szűkület

5. Okklúzió

megjelenése, abban az esetben is, ha az invazív koronária-angiográfia nem ír le kollaterális rendszert. Ennek hátterében a kontrasztanyag injektálása közötti különbség (CCTA esetén intravénásan, ICA során direkt arteriálisan), valamint a felvételek elkészítésének időzítése közötti különbség (CCTA esetén 20-30 másodperccel a kontrasztanyag bejuttatását követően) áll. A krónikusan elzáródott szegmentumok kalcifikációjának mértéke fontos információt nyújt az esetleges revaszkularizációt tervező invazív kardiológus számára. A kalcifikáció mértéke prognosztikus értékủ az intervenció sikerességének vonatkozásában.

\section{Bypassgraftok, stentek értékelése}

A koronária-bypassgraftok lefutásából adódóan mozgási mütermék kialakulásával kevésbé kell számolnunk, így ezeknek az ereknek az értékelésében a CCTA-nak kitűnő a specificitása és a szenzitivitása (15-17).

A graftok leírása során nyilatkoznunk kell a graft típusáról, a proximális és a distalis anastomosisról, valamint a graftteströl. A graftok számát a distalis anastomosisok száma határozza meg. A graftokat érintő stenosisok, thrombusok, aneurizmák, valamint a natív erek anastomosistól distalis szakaszának (kiáramlás) jellemzése szintén javasolt.

A koszorúerekbe implantált stentek értékelése, az instent restenosis mértékének megítélése nagyban függ a stent átméröjétől és anyagától. A jelenleg rendelkezésre álló adatok alapján a $3 \mathrm{~mm}$ átmérónél kisebb stentek értékelése nem ajánlott (18). Fontos körülmény, hogy a stenttöl distalisan ábrázolódó kontrasztanyag nem egyértelmű jele a stent átjárhatóságának.

\section{Non-koronáriás kardiális képletek}

A standard CCTA-vizsgálat során a szívüregek, a szívbillentyűk, a pericardium, a pulmonalis artériák, a pulmonalis vénák, a mellkasi aorta, a nagyerek és a vena cava rendszer is leképezésre kerül. Ezen képletek leírása is a CCTA-lelet fontos részét képezi.

A szívüregek jellemzése során nyilatkozni kell az üregméretekröl, a kamrafal vastagságáról (pl. dilatá- 
ció, hipertrófia), az üregekben ábrázolódó terimékről, esetleges fejlődési rendellenességekről. A kontrasztanyag-injektálás módjától függően a jobb szívfél ürege és fala is láthatóvá tehető. Az adatgyűjtés módjától függően a kamrák, a pitvarok és a szívbillentyűk funkciójára vonatkozó információk is nyerhetők. Fontos azonban megjegyezni, hogy a leggyakrabban alkalmazott vizsgálati protokollok használatával nem készül valós végdiasztolés, middiasztolés és végszisztolés felvétel, így az üregátmérők és a kamrafal vastagságának pontos megítélése nem lehetséges. A billentyűk tekintetében bizonyos morfológiai eltérések, mint a meszesedés jelenléte, vagy a billentyűk megvastagodása jól értékelhető a CCTA-vizsgálat során, továbbá a felvételezéshez használt szívciklustól függően stenosis és regurgitáció jelenlétére utaló eltérések kerülhetnek felismerésre.

A myocardium kontraszthalmozási mintázata a rutin CCTA során értékelhető. Az artériás fázisban igazolható hipodenzitás csökkent miokardiális perfúzió jelenlétére utal, amely kialakulhat korábbi miokardiális infarktus következményeként, vagy súlyos fokú koronáriastenosis jelenléte miatt, azonban fontos kiemelni, hogy a csökkent denzitás mütermék következménye is lehet. A lezajlott miokardiális infarktusra jellemző eltérés az érintett szegmentum elvékonyodása, lipiddús szövet felszaporodása miatt hipodenzitás, fali kalcifikáció, valamint üregi thrombusok jelenléte.

A bal kamrai myocardium megfelelő értékeléséhez az alábbi szempontokat megfontolása javasolt:

1. A fő kardiális síkokban (rövid tengely, négy üreg, két üreg) történő rekonstrukciók készítése.

2. 5-8 mm vastagságú, átlagolt denzitású multiplanáris vagy „minimum intensity projection” (MinIP) rekonstrukciók készítése, amelyek megkönnyítik a hipodenz területek elkülönítését.

3. Szűk ablak beállítás (pl. ablak szélesség 200, ablak közép 100) használata.

4. A szívciklus eltérő fázisaiban történő rekonstrukció a mütermékek biztosabb elkülönítéséhez. ( $A$ beam-hardening okozta mütermék jellemzően a basalis inferolateralis és a csúcsi területeket érinti.)

5. A myocardium-halmozás, a funkcionális információk és a koronária-anatómia átfogó elemzése.

6. 5-10 perccel az artériás fázisú felvételek elkészítése után második sorozat készítése, amely a késői kontraszthalmozás megjelenítésével a lezajlott infarktus elkülönítésében jelent segítséget.

A koronáriaszükület hemodinamikai szignifikanciájának megítéléséhez a CCTA-vizsgálat miokardiális perfúzióval egészíthető ki, amely során gyógyszeres vazodilatáció alatt készülnek felvételeket a szívről. Vazodilatáció előidézéséhez adenozin, regadenoson és dipyridamol alkalmazható. A vizsgálat során kialakuló csökkent halmozás iszkémia jelenlétére utal. Egyre bővülő irodalmi adatok alapján a terheléses CT-perfúzió noninferior a single photon emission CT (SPECT) perfúzióval szem- ben a myocardium iszkémia és az infarktus detektálása tekintetében (19-21).

\section{Extrakardiális képletek}

A kardiális struktúrákon kívül az extrakardiális képletek is leképezésre kerülnek mind a natív, mind a kontrasztos felvételeken. A FOV-tól (field of view) függően vizsgálható a mediastinum, a hilusok, a trachea, a bronchusok, a tüdőparenchyma, a pleura, a mellkasfal, a nyelőcső, a gyomor, a máj, a lép és a colon egy része. Az extrakardiális képletek eltérései magyarázhatják a negatív koronáriastátuszú betegek atípusos mellkasi panaszait.

\section{Mútermékek}

A folyamatosan mozgásban lévő, néhány milliméter átmérőjű koszorúerek ábrázolását számos körülmény nehezítheti. A mozgási, a kalcifikáció és a fémek okozta mútermékek, valamint a szuboptimális jel-zaj arány a képminőség romlását okozhatják, amelyek a lumenszükület mértékének túlbecsléséhez vagy a lézió súlyosságának alulbecsléséhez vezethetnek. Éppen ezért kiemelkedő jelentőségü, hogy a vizsgáló orvos a mütermékeket magabiztosan felismerje. Amennyiben a vizsgálat minősége „nem diagnosztikus”, megbízható értékelés nem kivitelezhető, a leletben ennek feltüntetése szükséges.

A lépcsős mütermék a rekonstrukció során illesztett, két, egymás után következő szívciklus közötti különbségből adódik. Okozhatja a mellkasfal mozgása a rossz ütemben végzett légzésvisszatartás miatt, aritmia, valamint a beteg felső testfelének vizsgálat alatti elmozdulása.

A szapora szívfrekvenciából eredő mozgási mütermékek a beteg megfelelő előkészítésével - bétareceptorblokkoló és szorongásoldó gyógyszer használatával - többnyire megelőzhetőek. A magas szívfrekvenciából, illetve szabálytalan ritmusból adódó mozgási mütermékek a szívciklus különböző fázisaiban történő rekonstruálással rendszerint minimalizálhatók, amenynyiben a felvételek retrospektív kapuzással készültek. A légzési mütermékek és a beteg vizsgálat alatti elmozdulásából adódó mütermékek nehezebben korrigálhatók.

A fémek, a tömény kontrasztanyag és a magas kalciumtartalmú képletek által okozott mütermékek, az úgynevezett „beam-hardening”, „blooming” és „streaking” artefaktumok szintén tévútra vihetik a vizsgáló orvost. A kalcifikáció mellett megjelenő beam-hardening nem kalcifikált plakk jelenlétére utaló képet mutathat. $A$ kalcifikált plakkok és stentek körül kialakuló blooming a stenosis mértékének túlbecslését eredményezheti. A kontrasztanyag-injektálás során a vena subclaviában és a vena cava superiorban áramló tömény kontrasztanyag okozta mútermékek nehezíthetik a bypassgraftok értékelését. Továbbá a magas jobb kamrai denzitás a jobb 
4. TÁBLÁZAT. A koronária-CT-angiográfia leletének javasolt felépítése

\section{Klinikai információk}

\begin{tabular}{|l|l|l|}
\hline Általános & A vizsgálat indikációja, ideje & Szükséges \\
\hline Demográfiai adatok & Név, nem, életkor, a vizsgálatot kérő orvos & Szükséges \\
\cline { 1 - 3 } & Testsúly, testmagasság, BMl & Javasolt \\
\hline Anamnézis & Tünetek, rizikófaktorok, releváns diagnosztikai vizsgálatok eredménye & Javasolt \\
\hline
\end{tabular}

\section{Vizsgálati adatok}

A vizsgálat típusa

A vizsgálóberendezés technikai leírása

$A z$ adatgyüjtés módja

premedikáció

A betegre vonatkozó adatok

\section{Eredmények}

A vizsgálat minősége

A vizsgálat minőségének átfogó értékelése

Ca-score (amennyiben elkészült)

Koronáriarendszer

Korábbi beavatkozások

Non-koronáriás erek

Szívüregek

Myocardium

Pericardium

Szívbillentyük

Mübillentyűk

Egyéb

Extrakardiális

Vélemény, javaslat

Képek

Vizsgálati üzemmód, kapuzás, dual energy

Csőáram, csőfeszültség, dózismoduláció

Dose-length product (DLP)

Vizsgált vagy rekonstruált fázis

Szeletvastagság

Szívfrekvencia, szívritmus

Komplikációk

Dominancia (bal, jobb vagy kiegyenlített)

Stenosis lokalizációja, súlyossága

Nem értékelhető szegmentumok

Stenosist okozó plakk típusa

Plakk hossza, oldalágak érintettsége

$\mathrm{PCl}$ : stentek lumenének megítélése

Kalcifikáció, fluidum, kóros megvastagodás rendelkezésre áll)

Eszközök: ICD/PM-elektródák helyzete
Ca-score, koronária-CT-angiográfia, bal pitvari CTA, kamrafunkció mérése stb.

Berendezés típusa, detektorszám, sugárforrások száma, rotációs idő

Szükséges

Javasolt

Javasolt

Javasolt

Javasolt

Javasolt

Opcionális

A kontrasztanyag típusa és mennyisége, béta-blokkoló, nitroglicerin,

Szükséges

Javasolt

Szükséges

Esetleges eredési/lefutási anomália, tágulat/aneurizma, miokardiális bridge

Szükséges

Szükséges

Szükséges

Szükséges

Pozitív remodelláció, alacsony denzitás, napkin-ring jel, szemcsés kalcifikáció

CABG: graft típusa, lefutása, anastomosisok, szűkületek megítélése

Szükséges

Szükséges

Javasolt

Javasolt

Javasolt

Szükséges

Aorta, vena cava, pulmonalis artériák, pulmonalis vénák leírása

Szükséges

Pulmonalis vénák morfológiája, ostium mérete

Opcionális

Mérete, esetleges terimék, thrombusok, söntök leírása

Szükséges

Funkcionális adatok, falmozgászavar (amennyiben az adat rendelkezésre áll)

Kalcifikáció, vastagság, stenosis, elégtelen záródás (amennyiben az adat

Típus és helyzet, pannus, thrombus, elégtelen mobilitás

Javasolt

Szükséges

Javasolt

Javasolt

Szükséges

Eltérések a tüdőben, mediastinumban, csontos képletekben, mellkasfalban stb.

Jellegzetes, releváns koronária-szegmentumok
Szükséges

Szükséges

Opcionális 


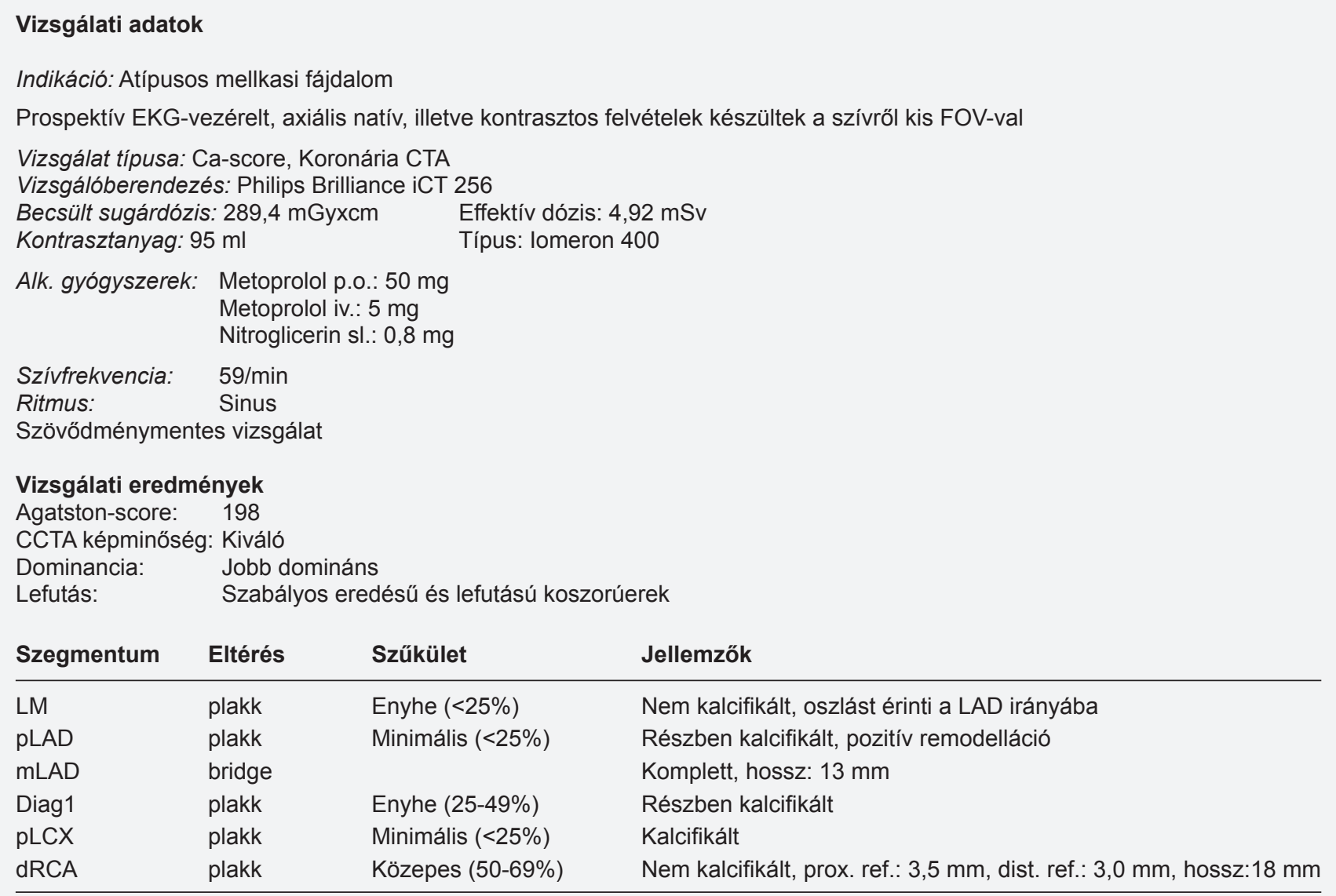

A szívizomban, szívüregekben, valamint a pericardiumon strukturális eltérés nem ábrázolódik. Az aortabillentyű minimális fokú meszesedése azonosítható. Az aorta descendens leképzésre került szakaszain apró meszes plakkok láthatók

\section{Extrakardiális lelet}

A koronáriák ábrázolására optimalizált felvételezési technika miatt a mediastinum és a tüdő részlegesen került látótérbe. A hilusokban és a mediastinumban kórosan megnagyobbodott nyirokcsomó nem látható. Az ábrázolódott tüdőterületeken aktuális kóros eltérés nem azonosítható

\section{Vélemény}

Összességében enyhe fokú koronária-ateroszklerózis. Súlyos fokú lumenszükület nem azonosítható

1. ÁBRA. Koronária CTA-lelet minta

koszorúér értékelését nehezítheti, ezért trifázisos kontrasztanyag-injektálási protokoll alkalmazása javasolt.

\section{A koronária-CT-angiográfiás lelet felépítése}

A leletnek tartalmaznia kell a vizsgálat indikációját, a klinikailag releváns információkat a betegről, a vizsgálat technikai paramétereit, továbbá nyilatkoznia kell a vizsgálat minőségéről, értékelhetőségéről. A lelet fő elemei a morfológiai elváltozások leírása, azok klinikai jelentősége, a vizsgáló orvos véleménye, esetleges terápiás javaslata.

Indikációk tekintetében öt fő csoportot különítünk el:

1. A koronáriák vizsgálata, lumenszükület és ateroszklerózis jelenlétének kizárása, illetve mértékének meghatározása, valamint koronária-anomália kizárása.
2. A nem koronáriás patológia értékelése, a nagyerek, szívüregek, szívizom, billentyűk és a pericardium vizsgálata.

3. A kamrafunkció és a falmozgászavar vizsgálata.

4. Alacsony-közepes kardiovaszkuláris rizikójú beteg vizsgálata, akinél stabil angina pectoris, vagy akut mellkasi fájdalom klinikai tünetei jelentkeznek.

5. Inkonkluzív iszkémia provokációs vizsgálatot követően.

A klinikailag releváns információk, a beteg kardiális anamnézise, a vizsgálat indikációjának alapját képező panaszok, a mellkasi fájdalom jellege, illetve a korábban elvégzett diagnosztikus módszerek eredményei segítséget jelenthetnek a vizsgáló orvosok számára a CCTA során leírt elváltozások klinikai jelentőségének felmérésében. A vizsgálati adatok ismertetése során mindig szükséges a vizsgálat típusának megnevezése (koronária- 
CT-angiográfia - CCTA, bal pitvari CT-angiográfia, Ca-score-vizsgálat, funkcionalitás vizsgálat stb.), az alkalmazott vizsgálati protokoll leírása, az alkalmazott kontrasztanyag típusának, mennyiségének, az injektálás módjának leleten történő rögzítése. Fontos a premedikáció során alkalmazott per os, illetve intravénás készítmények megnevezése és a dózisok feltüntetése. A vizsgálat minőségére utalhat, így a lelet megbízhatóságáról ad információt a vizsgálat alatti szívfrekvencia és ritmus feltüntetése. A sugárdózis leleten történő rögzítése nem szükséges, azonban klinikai adatbázisban való tárolása ajánlott. A leleten fontos szerepeltetni a vizsgálat során vagy azzal kapcsolatban fellépő komplikációkat (például paravasatio vagy kontrasztallergia). Az adatgyűjtés módjának jellemzése során ki kell térni az alkalmazott kapuzásra (prospektíven triggerelt axiális, vagy retrospektíven kapuzott helikális, illetve prospektíven triggerelt high-pitch helikális üzemmód), valamint az alkalmazott dóziscsökkentő módszerekre (például EKG-dózis-moduláció).

Az eredmények ismertetése előtt fontos nyilatkozni a vizsgálat minőségéről és az értékelést befolyásoló esetleges műtermékekről (mozgási, kalcium vagy fémek okozta mütermékek stb.). Ezek az információk segítséget nyújthatnak a klinikus orvos számára a lelet pontosságának megítélésében. A vizsgálat minőségének értékelésére alkalmazható standard osztályozási rendszer nem áll rendelkezésre. A legelterjedtebb felosztás „kiváló”, „jó”, „átlagos” és „nem diagnosztikus” minőségü vizsgálatokat különböztet meg.

\section{A koronária-CT-angiográfiás lelet tartalma}

A vizsgálati eredményeket a klinikusok számára is gyorsan áttekinthető, egyszerüen értelmezhető formában kell megfogalmazni. A leírásra kerülő képleteket három fő csoportra osztjuk:

1. A koronáriarendszer leírása.

2. A non-koronáriás kardiális képletek leírása.

3. Az extrakardiális képletek leírása.

További csoportot képezhet a Ca-score és a funkcionális vizsgálatok eredménye (4. táblázat).

A koronáriarendszer leírása során külön-külön vizsgálni kell az egyes erek eredését, lefutását, jelölni kell az esetleges anatómiai varianciákat, továbbá az ateroszklerózis jelenlétét. Amennyiben koronária-ateroszklerózis igazolódik, rögzíteni kell a szűkület mértékét, a plakk morfológiáját és kiterjedését. A plakkokat mésztartalmuk alapján az alábbi típusokra soroljuk:

1. kalcifikált plakkok,

2. nem kalcifikált plakkok,

3. a részben kalcifikált plakkokat további két alcsoportra felosztva döntően kalcifikált plakkok, illetve

4. döntően nem kalcifikált plakkok (22).

A „puha”, „lágy” és „zsírdús” plakk elnevezések kerülendők. A léziók jellemzésének része a plakk elhelyez- kedésének leírása (például bifurkációs, ér szájadékát involváló stb.), esetlegesen igazolható ulceráció leírása. Vulnerabilitásra utaló plakk jellegzetességek leírása is javasolt. Amennyiben a pozitív remodelláció, alacsony denzitás $(<60 \mathrm{HU})$, szemcsés kalcifikáció $(<3$ $\mathrm{mm}$ ) és napkin-ring jel közül legalább kettő azonosítható, az adott ateroszklerotikus plakk emelkedett rizikójú léziónak tekinthető $(3,23)$. A stenosisok jellemzésének része a pontos lokalizáció rögzítése, amelyhez az AHA módosított koronáriaszegmentum-modelljének használata ajánlott (2. táblázat).

Okkludált erek/érszakaszok tervezett rekanalizációja előtt fontos megemlíteni az oldalágak jelenlétét, a kalcifikáció kiterjedését, tortuozitást, illetve az okklúzió hozzávetőleges hosszát.

Bypassgraftok esetén a leletnek tartalmaznia kell a graftok (vagy okkludált graftcsonkok) számát, az áthidalás típusát, illetve a proximális anastomosis, a grafttest, a distalis anastomosis, valamint a kiáramlást adó natív koronária lumenének jellemzését hasonlóan a natív koronáriákhoz. Amennyiben rendelkezésre áll, korábbi invazív angiográfiás lelettel való összevetés is ajánlott.

Stentek elemzése során a helyzetük, megítélhetőségük, illetve a lumenobstrukció mértékének leírása szükséges. Amennyiben a stentlumen redukált, megkülönböztetünk enyhe fokú (<50\%-os szükület), jelentős fokú (50-99\%-os szúkület) instent restenosist, valamint stent-okklúziót.

A leletben nyilatkozni kell a non-koronáriás kardiális képletek (pericardium, billentyủk, szívüregek, szívizom) intaktságáról és az ábrázolódó extrakardiális képletek (nagyerek, tüdő, máj stb.) esetleges eltéréseiről.

A lelet különösen fontos részét képezi a vizsgálatot végző orvos véleménye, amely összegzi a klinikailag releváns elváltozásokat. A vélemény további kivizsgálási tervet (például stresszteszt, invazív kardiológiai kivizsgálás elvégzését) és terápiás javaslatokat (például szekunder prevenciós kezelés bevezetését) is tartalmazhat. Javasolt, hogy a lelethez mellékeljék a felvételek válogatott képanyagát általánosan használható digitális formátumban. A mellékelt képanyagban célszerü kiemelni a hangsúlyos eltérést mutató koronáriaszegmentumokat, illetve egyéb struktúrákat.

\section{Irodalom}

1. Leipsic J, et al. SCCT guidelines for the interpretation and reporting of coronary CT angiography: a report of the Society of Cardiovascular Computed Tomography Guidelines Committee. J Cardiovasc Comput Tomogr 2014; 8(5): 342-58. https://doi.org/10.1016/j. cct.2014.07.003

2. Achenbach, S. and P. Raggi, Imaging of coronary atherosclerosis by computed tomography. European Heart Journal 2010; 31(12): 1442-1448. https://doi.org/10.1093/eurheartj/ehp470

3. Maurovich-Horvat $\mathrm{P}$, et al. Comprehensive plaque assessment by coronary CT angiography. Nat Rev Cardiol 2014; 11(7): 390-402. https://doi.org/10.1038/nrcardio.2014.60

4. Hoffmann $U$, et al. Noninvasive assessment of plaque morphology 
and composition in culprit and stable lesions in acute coronary syndrome and stable lesions in stable angina by multidetector computed tomography. Journal of the American College of Cardiology 2006; 47(8): 1655-62. https://doi.org/10.1016/j.jacc.2006.01.041

5. Dewey M, et al. Evaluation of global and regional left ventricular function with 16-slice computed tomography, biplane cineventriculography, and two-dimensional transthoracic echocardiography: comparison with magnetic resonance imaging. J Am Coll Cardiol 2006; 48(10): 2034-44. https://doi.org/10.1016/j.jacc.2006.04.104

6. Brodoefel $\mathrm{H}$, et al. Sixty-four-slice CT in the assessment of global and regional left ventricular function: comparison with MRI in a porcine model of acute and subacute myocardial infarction. Eur Radiol 2007; 17(11): p. 2948-56. https://doi.org/10.1016/j.jacc.2006.04.104 7. Ryan R, et al. Cardiac valve disease: spectrum of findings on cardiac 64-MDCT. AJR Am J Roentgenol 2008; 190(5): W294-303.

https://doi.org/10.2214/AJR.07.2936

8. Lemol K, et al. Computed tomographic analysis of the anatomy of the left atrium and the esophagus: implications for left atrial catheter ablation. Circulation 2004; 110(24): 3655-60.

https://doi.org/10.1161/01.CIR.0000149714.31471.FD

9. Agatston AS, et al. Quantification of coronary artery calcium using ultrafast computed tomography. J Am Coll Cardiol 1990; 15(4): 827-32 https://doi.org/10.1016/0735-1097(90)90282-T

10. Rutten A, Isgum I, Prokop M. Coronary calcification: effect of small variation of scan starting position on Agatston, volume, and mass scores. Radiology 2008; 246(1): 90-8. https://doi.org/10.1016/0735-1097(90)90282-T

11. Budoff MJ, et al. Diagnostic performance of 64 -multidetector row coronary computed tomographic angiography for evaluation of coronary artery stenosis in individuals without known coronary artery disease: results from the prospective multicenter ACCURACY (Assessment by Coronary Computed Tomographic Angiography of Individuals Undergoing Invasive Coronary Angiography) trial. J Am Coll Cardiol 2008; 52(21): 1724-32.

https://doi.org/10.1016/j.jacc.2008.07.031

12. Raff GL, et al. Diagnostic accuracy of noninvasive coronary angiography using 64-slice spiral computed tomography. J Am Coll Cardiol 2005; 46(3): 552-7. https://doi.org/10.1016/j.jacc.2008.07.031

13. Achenbach $S$, et al. Detection of calcified and noncalcified coronary atherosclerotic plaque by contrast-enhanced, submillimeter multidetector spiral computed tomography: a segment-based comparison with intravascular ultrasound. Circulation 2004; 109(1): 14-7. https://doi.org/10.1161/01.CIR.0000111517.69230.0F

14. Cheng V, et al. Moving beyond binary grading of coronary arterial stenoses on coronary computed tomographic angiography: insights for the imager and referring clinician. JACC Cardiovasc Imaging 2008; 1(4): 460-71. https://doi.org/10.1016/j.jcmg.2008.05.006

15. Jones $\mathrm{CM}$, et al. Multi-detector computed tomography in coronary artery bypass graft assessment: a meta-analysis. Ann Thorac Surg 2007; 83(1): 341-8. https://doi.org/10.1016/j.athoracsur.2006.08.018 16. Achenbach $S$, et al. Noninvasive, three-dimensional visualization of coronary artery bypass grafts by electron beam tomography. Am J Cardiol 1997; 79(7): 856-61.

https://doi.org/10.1016/S0002-9149(97)00003-9

17. Lu B, et al. Evaluation of coronary artery bypass graft patency using three-dimensional reconstruction and flow study on electron beam tomography. J Comput Assist Tomogr 2000. 24(5): 663-70. https://doi.org/10.1097/00004728-200009000-00001

18. Nakamura K, et al. Impairment factors for evaluating the patency of drug-eluting stents and bare metal stents in coronary arteries by 64-slice computed tomography versus conventional coronary angiography. Int J Cardiol 2008; 130(3): 349-56.

https://doi.org/10.1016/j.ijcard.2007.08.104

19. Rossi A, et al. Diagnostic performance of hyperaemic myocardial blood flow index obtained by dynamic computed tomography: does it predict functionally significant coronary lesions? Eur Heart J Cardiovasc Imaging 2014; 15(1): 85-94. https://doi.org/10.1093/ehjci/jet133 20. Bamberg F, et al. Detection of hemodynamically significant coronary artery stenosis: incremental diagnostic value of dynamic CT-based myocardial perfusion imaging. Radiology 2011; 260(3): 689-98. https://doi.org/10.1148/radiol.11110638

21. Rochitte CE, et al. Computed tomography angiography and perfusion to assess coronary artery stenosis causing perfusion defects by single photon emission computed tomography: the CORE320 study. Eur Heart J 2014; 35(17): 1120-30.

https://doi.org/10.1093/eurheartj/eht488

22. Maurovich-Horvat $P$, et al. Methods of plaque quantification and characterization by cardiac computed tomography. J Cardiovasc Comput Tomogr 2009; 3(Suppl 2): S91-8.

https://doi.org/10.1093/eurheartj/eht488

23. Cury RC, et al. CAD-RADS(TM) Coronary Artery Disease Reporting and Data System. An expert consensus document of the Society of Cardiovascular Computed Tomography (SCCT), the American College of Radiology (ACR) and the North American Society for Cardiovascular Imaging (NASCl). Endorsed by the American College of Cardiology. J Cardiovasc Comput Tomogr 2016; 10(4): 269-81. https://doi.org/10.1016/j.jcct.2016.04.005 